\title{
Teaching Literature through the Arts: A Few Notes on Teaching Aldous Huxley's Point Counter Point through Beethoven's Music
}

DANA BĂDUlescu ${ }^{1}$

“The world, transformed by industry's bold hand, The human heart, by new-born instincts moved,

That have in burning fights been fully proved, Your circle of creation now expand. Advancing man bears on his soaring pinions, In gratitude, art with him in his flight, And out of Nature's now-enriched dominions New worlds of beauty issue forth to light." Friedrich Schiller, The Artists

$\approx$ The present article examines a teaching experiment undertaken by the author in order to point out not only the importance of the arts and aesthetics, but also their limitations. It also argues that, despite these limitations, the spirit of the arts opens us up to freedom and flexibility. Their purpose is not to give answers or solutions, but to make us question the most troubling aspects of our existence. The last chapter of Aldous Huxley's novel Point Counter Point invites an approach that should do justice to its musical qualities. Apart from borrowing the counterpoint technique from music, it also references music, therefore lending itself to performance, which renders its dramatic force with a strong impact upon readers.

Keywords: aesthetic education, intermediality, the "musicalisation of fiction", intellectualism, science, performance 


\section{Poučevanje književnosti prek umetnosti: nekaj zapisov o poučevanju romana Kontrapunkt življenja avtorja Aldousa Huxleyja prek Beethovnove glasbe}

DANA BĂDULEscu

$\propto$ V prispevku je predstavljena analiza eksperimenta, ki ga je izvedla avtorica; ta je želela poudariti ne samo pomembnost umetnosti in estetike, ampak tudi njune omejitve. Zagovarja, da kljub tem omejitvam duh umetnosti spodbuja fleksibilnost in svobodo. Njun namen ni dajati odgovorov ali rešitev, ampak spodbujati lastno spraševanje o najbolj skrb vzbujajočih vidikih obstajanja. V zadnjem poglavju novele Point Counter Point [Kontrapunkt življenja] Aldousa Huxleyja je uporabljen pristop, ki izstopa s svojimi glasbenimi kvalitetami. Poleg tega, da si sposodi tehniko kontrapunkta iz glasbe, se ustrezno sklicuje na glasbo in si jo sposoja pri izvedbi, kar z njeno dramatično močjo naredi močen vtis na bralce.

Ključne besede: estetska vzgoja, intermedialnost, »muzikalizacija fikcije«, intelektualnost, znanost, izvedba 


\section{The importance of aesthetic education from Schiller's times to the present day}

At the end of the $18^{\text {th }}$ century, in a plea for what he called "the aesthetic education of man", Friedrich Schiller stated in his Second Letter:

The course of events has given a direction to the genius of the time that threatens to remove it continually further from the ideal of art. For art has to leave reality, it has to raise itself bodily above necessity and neediness; for art is the daughter of freedom, and it requires its prescriptions and rules to be furnished by the necessity of spirits and not by that of matter. But in our day it is necessity, neediness, that prevails, and bends a degraded humanity under its iron yoke. Utility is the great idol of the time, to which all powers do homage and all subjects are subservient. In this great balance of utility, the spiritual service of art has no weight, and, deprived of all encouragement, it vanishes from the noisy Vanity Fair of our time. The very spirit of philosophical inquiry itself robs the imagination of one promise after another, and the frontiers of art are narrowed, in proportion as the limits of science are enlarged. (http://www.bartleby. com/32/502.html)

More than two centuries have passed since Schiller alerted his contemporaries to the perils of "the genius of the time", which exalted utilitarianism to the detriment of the spiritual values inherent in art. The whole of the $19^{\text {th }}$ century triumphantly marched along this path, guided by the genius that Schiller and other intellectuals of his time abhorred. In England, Jeremy Bentham, the father of utilitarianism, followed by John Stuart Mill, a proponent of utilitarianism who developed the theory of scientific method, set the frameworks of a system that grew oppressively and ruthlessly mechanical, coldly scientific and sterile. Thus, Schiller's alarmed and alarming remarks did not lose relevance; on the contrary, they were confirmed by a new century that sealed the import of this genius.

The artists of the $20^{\text {th }}$ century felt largely divided between fascination towards the new Zeitgeist, which was essentially modern, and disinclination towards its stifling materialism and mercantilism. They either embraced aesthetics that related their art to science, technology and progress, or rejected and resented their flux and terror.

In the $21^{\text {st }}$ century, we have inherited Schiller's modernity, which has undergone several stages in which it has sharpened or, more recently, has become liquid, as Zygmunt Bauman would put it. Is Schiller's sense of alienation and apprehension still relevant today? 
Schiller concludes his Second Letter on a persuasive note, whose meaning endures:

I hope that I shall succeed in convincing you that this matter of art is less foreign to the needs than to the tastes of our age; nay, that, to arrive at a solution even in the political problem, the road of aesthetics must be pursued, because it is through beauty that we arrive at freedom. (http:// www.bartleby.com/32/502.html)

\section{Werner Wolf's theory of "intermediality"}

In his book The Musicalization of Fiction. A Study in the Theory and History of Intermediality, Werner Wolf (1999) defines "intermediality" as participation, that is, "the participation of more than one medium of expression in the signification of a human artefact" (p. 1). According to Wolf's explanation, the concept grew out of the interest in intertextuality, and both are the offshoots of a tendency in our contemporary culture towards opening out and exploring pluralities in interdisciplinary endeavours.

Although he argues that intermediality is a major characteristic of postmodernism, where medial boundaries are transgressed in order to create an illusion of reality in multi-media cyberspace, and where "installations" that experiment with a sense of synthesis of the arts and electronic media challenge our expectations of "closure", Wolf states at the same time that intermediality has a long history. The idea that the arts borrow techniques from one another can be traced back to Aristotle and to Horace's ut pictura poesis, continuing with Lessing's Laocoön, the Baroque trompe l'oeil techniques and the sense most modernist works of art give that the arts cannot be seen as separate media. Huxley's interest in the arts and in the sciences originated in his desire to access some essential truth, and it found a favourable context in the culture of his time.

Wolf points out that the relationship between literature and the other arts is very old. Ekphrasis is an illustration of how words can picture objects or works of art, appealing to our imagination, while staged drama and opera have always crossed medial boundaries. As old as it may be, intermediality has always been questioned, sometimes even by those who practise it. Despite entitling his novel Point Counter Point in order to suggest its intermedial nature, Huxley threw the very principle that underpins the novel, the "musicalisation of fiction", into serious doubt by including the figure of a novelist whose raison dêtre is to render it problematic.

Long before the term was invented, Huxley wrote with intermediality at the back of his mind, reflecting upon it in essays as well as in his metamedially 
self-reflexive novels. In "And Wanton Optics", he stated that:

The artist can, if he so desires, break down the bulkheads between the compartments and so give us a simultaneous view of two or more of them at a time. So seen, reality looks exceedingly queer. Which is how the ironist and the perplexed questioner desire it to look. (Huxley quoted in Birnbaum, 2009, p. 70)

\section{Huxley and music}

Born to a family with a solid intellectual tradition, Huxley became one of the most outstanding intellectuals of his time. He received an education that paid equal due to the sciences and the arts. During World War I, he frequented the Bloomsbury Group, an extremely arty circle of friends, and in its aftermath he and his family lived in Italy, where he would visit his friend D. H. Lawrence, who served as the model of the type of intellectual that grew into the figure of Mark Rampion in Point Counter Point.

Being of these two minds, Huxley could assess their worth and their follies from within. Like Lawrence, alias Mark Rampion, Huxley, who put a lot of himself in Philip Quarles, the novelist in the novel, found that the pursuit of science was a path leading to the sterility of the soul.

In "Aldous Huxley as Music Critic", Basil Hogarth (1935), Huxley's contemporary, argues that "Aldous Huxley is, in some respects, the most remarkable literary man who has ever written on musical subjects" (p. 1079). For a while, the writer was the accredited music critic of a weekly journal. Judging Huxley's competence and skills as a music critic, Hogarth (1935) points to the unique coexistence within his mind of the sciences and the arts, which actually enabled him to look at one in the light of the other:

He stands indeed alone, not only amongst men of letters, but amongst musical critics, by reason of his unique method of thinking, the product of a strictly scientific method pursued to its ultimate logical conclusion, allied to a fundamental aesthetic philosophy that enable him to classify the musical experiences swiftly and succinctly. (p. 1079)

\section{"Huxley's devout regard for Beethoven" and "the musi- calisation of fiction"}

In writing Point Counter Point, Huxley (1994) aspired to the purity of music through what Philip Quarles calls in his Notebook "the musicalisation of fiction": 
The musicalisation of fiction. Not in the symbolist way, by subordinating sense to sound. (Pleuvent les bleus blaisers des astres taciturnes. Mere glossolalia.) But on a large scale, in the construction. Meditate on Beethoven. The changes of moods, the abrupt transitions. (p. 384)

Of all musicians, Beethoven provided Huxley with a large-scale approach to the purity that Quarles - and through Quarles, Huxley himself wanted to achieve in the novel. Chapter XXII of Point Counter Point consists of Philip's notebook entries, which reinforce the novel's self-reflexive nature. Wolf (1999) contends that "in works in which intermediality appears repeatedly or in a conspicuous way", which Huxley's novel makes obvious in the very title, "intermediality here is coupled with a tendency towards meta-reflection on problems of mediality or fictionality and related questions (just as prominent intertextuality may well be found in texts which at the same time are highly metatextual)" (p. 49).

Hogarth (1935) remarks upon "Huxley's devout regard for Beethoven" (p. 1080). Quoting the music critic's glosses on Beethoven, Hogarth explains that he was aware of the passion in Beethoven's music, which is also to be found in primitive music, with the significant difference that Beethoven's passion was "transmuted". So ethereal and spiritual did Beethoven's music become to Huxley's mind that,

In such works as the "Hammerklavier" Sonata Beethoven passed into the transcendental region of pure art. (Huxley quoted in Hogarth, p. 1080)

In Point Counter Point, Philip Quarles meditates on the harmonious transition from "majesty" to its extreme ("a joke"), comedy not simply being followed by, but "hinting at prodigious and tragic solemnities in the scherzo of the C sharp minor quartet," not mere variations but almost a Möbius strip where "a theme is stated, then developed, pushed out of shape, imperceptibly deformed, until, though still recognizably the same, it has become quite different" (Huxley, 1994, p. 384). After pondering Beethoven's masterful achievement of this in music, Quarles wonders: "Get this into a novel. How?" (Huxley, 1994, p. 384). Quarles believes that abrupt transitions are achievable in the novel provided there are sufficient characters and "parallel, contrapuntal plots. While Jones is murdering a wife, Smith is wheeling the perambulator in the park" (Huxley, 1994, p. 384). This may be a solution to the simultaneity that can be suggested both in music and in verbal art by what Wolf (1999) calls "the juxtaposition of 'contrapuntal' elements in rapid succession in order to simulate a 
(polyphonic) simultaneity of parts, though in reality only one chain of signifiers is present at a time" (p. 21). Quarles continues to describe the effects of alternating themes and modulating "by reduplicating situations and characters" (Huxley, 1994, p. 384), which is similar to variations in music. Yet another technique Quarles considers if musicalisation of fiction is desired on a large scale is the "god-like" way of modulating aspects:

He will modulate from one to the other - as from the aesthetic to the psycho-chemical aspect of things, from the religious to the physiological or financial. (Huxley, 1994, p. 385)

What is the musicalisation of fiction? Whereas Huxley, through his fictionalised persona Philip Quarles, meditates on how to achieve it, Wolf (1999) defines it in the broader context of intermediality:

It consists in an (in most cases) intentional shaping of the discours (affecting, e.g., the linguistic material, the formal arrangement or structure of the narrative, and the imagery used) and sometimes also of the histoire (the content structure of the narrative) so that verifiable or at least convincingly identifiable 'iconic' similarities or analogies to (a work of) music or to effects produced by it emerge in the fictional text. As a result, the reader has the impression that music is involved in the signifying process of the narrative not only as a general signified or a specific - real or imaginary - referent but also that the presence of music can indirectly be experienced while reading. (p. 52)

\section{A Romanian philosopher's school}

Constantin Noica (2002), Romanian philosopher, essayist and poet, a political prisoner during the communist regime, wrote in his Philosophical Diary:

A book that you take from the book case, a Prelude by Bach that you play in the evening when everything is quiet, or an example of intellectual serenity are much more instructive than a lesson. Those young people see that you want to embody an idea and they also start embodying one. (Maybe the 'one and only thought' that Pârvan spoke about.) I think this school must be established. ${ }^{2}$ (p. 10)

Noica's idea of a school may seem like the dream of an incurable dreamer, but it is a projection of what should ideally be the primary goal of education:

2 All of the passages from Noica's Philosophical Diary are the author's translation. 
an activity aimed at leading disciples towards self-discovery in a way that allows their freedom. It should not stiffly and discouragingly "teach" them through some inhibiting "authority" and authoritarian methods; it should be an opening out, thereby encouraging empathy:

The thought of the school, of that school where nothing should actually be taught, is my obsession. States of mind, that is what the others must be given; not content, not advice, not lectures. That is why lessons are not needed. (Noica, 2002, pp. 9-10)

\section{Playing Beethoven to make a point}

In the last chapter of Point Counter Point, Spandrell, a Baudelairean character whose blasé attitude has reached a climax, wants Mark Rampion to hear Beethoven's minor quartet heilige Dankgesang eines genesenen an die Gotthed, in dir lydischen Tonart, which proves "all kinds of things - God, the soul, goodness - unescapably" (Huxley, 1994, p. 560). Rampion is rather surprised by Spandrell's concern, but Spandrell explains his wish in terms of communion and empathy: "Because I believe in you and, if you confirm, I shall believe in myself" (Huxley, 1994, p. 560).

Spandrell is the director of the scenario in this episode of the novel. He has coldly calculated his own assassination, writing a note to the Secretary General of the Brotherhood of British Freemen in order to inform him where the murderer of Everard Webley will be able to be found the next day. He adds that Webley's killer "will probably answer the bell in person", carefully planning to do it himself, and - for a surplus of effect - that "He is armed and desperate" (Huxley, 1994, p. 563).

Robert Baker (1974) argues that "Spandrell is, for Huxley (and Rampion), the 'modern aesthete', the product of an excessive intellectual and aesthetic refinement that has rendered him sexually and socially sterile" (p. 132). He is the epitome of Lawrence's "sex in the head", by which he means excessive cerebration. In his novels, Lawrence put this idea in the mouth of Rupert Birkin, a spokesman for his own theories in Women in Love, while in Huxley's novel Lawrence's abhorrence of it is voiced by Rampion.

Baker (1974) speaks about the "Gothic intensity" (p. 132) with which Spandrell actually stages his own death against the background of Beethoven's string quartet. After loitering along the river bank of the Thames, while whistling "the opening phrases of the Lydian melody from the heilige Danksgesang" (Huxley, 1994, p. 562), he writes the note, puts it in an envelope and posts it. By using the word "phrases" in this context, Huxley subtly reinforces the similitude 
between music and text, both of which rely on what Wolf (1999) calls "discrete signifying units" (p. 15). Although it is not easy to find the exact correlatives of these units in the two arts, what actually matters in this particular chapter of Point Counter Point is Huxley's clear intention to establish intermediality, which he planned for the novel on a large scale.

The walk reveals to Spandrell the filth of civilization - his attention focuses upon the refuse hurried by a tiny stream into the gutter - counterpointed, in his head, by Beethoven's music, which, Spandrell says to himself, is a proof of God's existence, but only so long as the music is there. In his despair, Spandrell wonders:

When the bows were lifted from the strings, what then? Garbage and stupidity, the pitiless drought. (Huxley, 1994, p. 562)

Spandrell's eyes behold a city, which stands for the whole of Europe of those times, described with an imagery that is redolent of T. S. Eliot's The Waste Land. Spandrell and the voice in Eliot's poem strike notes of anguish at the sight of the arid cityscape, which is suggestive of the sterility of modern civilisation and of their own mind cast.

Spandrell turns his argument into the spectacle that he plays out in front of Rampion the next day: he starts by saying that "the heilige Dankgesang is the crucial part" (Huxley, 1994, p. 564), and while saying it he starts playing the music. For one more page, Spandrell is silent, letting the music speak, but this is where Huxley the music critic carries on, through the narrative voice, which uses words to evoke the music and to shed light upon it. After thirty bars that have built up heaven, "the character of the music suddenly changed" (Huxley, 1994, p. 564). This is a transition that Huxley the music critic praised so much. At this point in the show, Spandrell intervenes and comments: "He's feeling stronger; but it's not so heavenly" (Huxley, 1994, p. 564). Playing for his life, which he knows will end shortly, Spandrell desperately needs to prove God's existence in his last act, and his interrogation carries overtones of despair. He asks: "Isn't it a proof?" (Huxley, 1994, p. 565). Rampion, who is an advocate of the balance between body and spirit, cannot see in this pure music the same thing that stirs Spandrell's elation. For Rampion, "It's the art of a man who's lost his body," while Spandrell, counterpointing his argument, hurries to add in a dramatic tone: "But discovered his soul" (Huxley, 1994, p. 565). The man who knows he has lost his soul pines for it, and although Rampion seems to jump to conclusions before the movement is over, Spandrell insists that he should listen to it through before judging. The tension between their radically opposing views accumulates as the music plays in the background. 
At the end of the movement, Spandrell turns the record over and lowers the needle, which is an intermission in the show. Rampion admits: "It is heaven, it is the life of the soul. It's the most spiritual abstraction from reality I've ever known" (Huxley, 1994, p. 565). However, he does not value it as Spandrell does; for Rampion, its abstraction is ultimately inhuman. This "bodilessness", as he calls it, cannot stand for the wholeness of the human being, which for him should be body and soul in harmony.

Huxley's narrator pauses the scene closely following the pauses in Beethoven's quartet. After the music begins again, Spandrell's own doubts vanish, but Rampion remarks that it is too good, meaning "Not human. If it lasted, you'd cease to be a man. You'd die" (Huxley, 1994, p. 567). The music continues while the men remain silent, and before the movement ends, Spandrell answers the doorbell, as planned. Hearing a pistol shot, Mary and Mark Rampion jump up and run to the door to see three men in the uniform of British Freemen looking down at Spandrell's body. The sound of music wafts through the open door and seems to express "absolute rest" (Huxley, 1994, p. 568), which is the state eventually attained by Spandrell, just as it is eventually attained by everybody. However, as Spandrell had thought while taking his walk the day before he died, when the bows are lifted from the strings, the sound to be heard is "only the scratching of the needle on the revolving disk" (Huxley 1994, p. 568). As Milton Birnbaum (2009) argues, "the reader is catapulted from the music of Beethoven into the prosaic ugliness of the daily realities" (p. 87).

\section{Mise en abyme through performance in class}

The formal technique of mise en abyme was Huxley's favourite. In the creative arts and literary theory, mise en abyme, similar to Chinese boxes, is a technique by which an image contains a smaller copy of itself, in a sequence that gives the impression of recurring infinitely. Huxley developed this as an aesthetic frame that translated his interest in metareference.

Quarles starts toying with the idea of putting a novelist in the novel just as Huxley himself had done when he put Philip Quarles in Point Counter Point - in order to create a mise en abyme effect that transcends the boundaries of the novel and involves the reality outside it, too:

But why draw the line at one novelist inside your novel? Why not a second inside his? And a third inside the novel of the second? And so on to infinity, like those advertisements of Quaker Oats where there's a Quaker holding a box of oats, on which is the picture of another Quaker holding another box of oats, on which etc., etc. At about the tenth remove 
you might have a novelist telling your story in algebraic symbols or in terms of variations in blood-pressure, pulse, secretion of ductless glands and reaction times. (Huxley, 1994, p. 385)

At one of the removes, one might have the instructor performing the performance in the novel, which is the dialogue between Spandrell and Mark Rampion with Beethoven's music as what Wolf (1999) calls intermedial "thematisation" (p. 44). By performing it as described below, the students have a communal experience of a text that is intermedial by design, as well as being metamedially self-reflexive.

\section{Performing Huxley's scene against the background of Beethoven's music}

Huxley's use of counterpointing ideas implies that no particular idea is uniquely valid. There is no absolute truth, only a proliferation of truths set in dramatic contrast, like in the last scene of the novel, where neither the body nor the spirit can prevail, and where neither Spandrell's "moral masochism" (as Baker calls it) nor Rampion's balance wins the case.

Nonetheless, Huxley constructed his whole novel upon the musical technique of counterpoint, and in the last chapter he employed the purest form of music, which he considered the epitome of its kind, i.e., Beethoven's String Quartet No. 15 in A minor, Op. 132. Referring to Beethoven's last sonatas and later string quartets, Huxley the music critic wrote:

They have no theme but themselves. A large amount of the supreme music of the world is not merely not written around any external subject: it is not even expressive of any particular emotion; in short - it is just music. (Huxley quoted by Hogarth, 1935, p. 1081)

As a novelist, Huxley translated the abstract spirit of Beethoven's music into the passages where the narrative voice does something very close to performing the music, which is interspersed with the dialogue between Spandrell and Rampion reinforcing its effect and transitions. Although emotions are played down, they seethe underneath until they are brutally silenced, as the music itself dies away. The only remaining sound is discordant and metallic, and Huxley deliberately chose this way of alternating sounds in order to foreground the intensity and dramatic force of music itself.

One way of teaching this scene is performing it with a view to putting the class into what Noica would call a "state of mind". When the narrative voice reaches the point when Spandrell lowers the needle onto the surface of the 
gramophone box, everything should be in place for music to fill the space of the classroom, while the narrative voice, performed by the teacher, continues to read the passage with the music in the background.

The pauses in the text are also the pauses between the movements, and they are marked. When Spandrell says "Listen", the music stops, and the next paragraph begins with "The music began again" (Huxley, 1994, p. 566). If it is to achieve maximum impact on the class, the instructor's performance should carefully observe the dramatic effect of the verbal dialogue, and to an equal extent the intermedial dialogue between the verbal medium of the text and the music it not only references but enacts.

Relying on music and dialogue, this scene in Huxley's novel invites performance. Once performed, i.e., acted out, the words on the page and the music join and reinforce each other, just as Huxley intended them to.

\section{Oral presentation of literature vs. silent reading}

As early as 1915, Maud May Babcock contended that:

All literature was produced to be voiced and heard, just as music finds the end of its production for hearing ears. Interpretation means oral translation - histrionically it indicates a transition from the dead printed or written form into a living, breathing experience; this experience impresses itself upon the life of both listener and interpreter producing results very close to the impression of real experience. (Babcock quoted in Calingacion http://magyarszak.uni-miskolc.hu/kiadvanyok/ drama2002/ea/belen.htm)

Indeed, performance may be a very strong incentive for students of literature. It brings the text to life, staging it, acting it out; it puts the text under a spotlight, releasing its latent energies. As Babcock hints, apart from making an impression upon the listener, performance also makes an impression upon the performer/interpreter, thus bringing them close and establishing a communion. Through performance, the text becomes a shared space.

Compared to silent reading, which obviously has its own upsides and rewards, especially for individual or solitary readers, an intelligent, imaginative and lively oral presentation of a lyric poem, a dramatic selection, or a prose passage is often the best classroom practice. However, as Wolf argues, the problem with reading fiction aloud in order to emphasise its musical qualities and effects may be that it has never been regarded primarily as sound. Consequently, Wolf (1999) sees it as an effort that is needed "to remind the reader of fiction of the 
original sound quality of the letters he is perusing" (p. 16). What justifies the performance of this particular chapter in Huxley's novel in class, however, is its essentially dramatic and "dialogic" (in Bakhtin's sense of the word) nature. Meaning is not located in any particular character or scene. Huxley's purpose is to explore the vast space where meaning is negotiated through the dialogue of the characters and the arts. It is through performance that the essential significances of the text become obvious.

Communication studies have shown that learning or knowledge acquisition depends upon the individuals' capacity to retain, understand and interpret a message that is communicated to them, which is generally termed "comprehension". Of course, their comprehension is triggered by the mode of presentation. Performance, which ensures first-hand participative experience, increases the students' emotional involvement in the comprehension process.

Reading Huxley's passages in which not only the characters and the narrator speak, but music itself "speaks" while playing the music that becomes the protagonist of the chapter, the text and the music enhance each other. The text makes the listeners comprehend the music as the words evoke it:

A single violin gave out a long note, then another a sixth above, dropped to the fifth (while the second violin began where the first had started), then leapt to the octave, and hung there suspended through two long beats. (Huxley, 1994, p. 563)

The words in the text relate the music to its creator and his tragic destiny, which turns the music itself into a miracle, then to the modern technology that enables its sounds to be recorded, and to an imaginary landscape suggested by its unfolding:

More than a hundred years before, Beethoven, stone deaf, had heard the imaginary music of stringed instruments expressing his inmost thoughts and feelings. He had made signs with ink on ruled paper. A century later, four Hungarians had reproduced from the printed reproduction of Beethoven's scribbles that music which Beethoven had never heard except in his imagination. (Huxley, 1994, pp. 563-564)

This passage highlights the tremendous role of performance, and students may wish to relate Beethoven's "scribbles" and the Hungarians' performance, which gives life to the scores, to the text read out and the music played, a combined performance that gives life both to Beethoven's music and to Huxley's text.

Translating its most abstract characteristics into a descriptive vocabulary of concrete terms with imperceptible transitions, the narrative voice induces 
the calm that is created by the music itself, while at the same time imagining a landscape "drawn" by it:

Slowly, slowly, the melody unfolded itself. The archaic Lydian harmonies hung on the air. It was an unimpassioned music, transparent, pure and crystalline, like a tropical sea, an Alpine lake. Water on water, calm sliding over calm; the according of level horizons and waveless expanses, a counterpoint of serenities. (Huxley, 1994, p. 564)

Just listening to the music, its imaginative potential may fail to have its full impact on the listener. The text fulfils it, magnifying it, as a painting whose beauty increases if it is set in the right frame. But for the text, there may be bars that lose their precious shine. The text signals the abstractedness of music, while at the same time rendering it concrete and sensible. Likewise, the text's depths are fathomed by the music. Until the climax of the "scratching of the needle on the revolving disk" (Huxley, 1994, p. 568), text and music have joined their languages.

\section{An integrative approach to teaching literature and the arts}

Schiller may have been an idealistic late $18^{\text {th }}$ century philosopher, but there are contemporary researchers who argue that aesthetic response is an important communication factor. Calingacion quotes Lindauer, who showed that "aesthetics deals not only with the interrelationships between the arts and society but also with the practical - art appreciation and education - and the applied - advertising and propaganda" (Lindauer quoted by Calingacion http:// magyarszak.uni-miskolc.hu/kiadvanyok/drama2oo2/ea/belen.htm).

Huxley could not have agreed more with this statement, since he was worried by the manipulative role of advertising and propaganda, two aspects that transform the system of his Brave New World into a totalitarian system. However, the effects of advertising are not always the worst. Jameson and other theorists of the postmodern argue that today's societies have turned advertising into an art. The point of all of this is that we live in a world where fields are interconnected; therefore, our teaching practices should aim at an integrative approach, where literature and reading literature should be integrated into a larger schema. 


\section{Conclusion}

Since Schiller's times, modern civilisation has developed a spirit of utilitarianism, which has had an impact upon education, too. Education has become increasingly job-oriented and targeted. Since the sciences have become its driving force, the humanities and the arts have been in decline.

Huxley was emblematically the conscience of his times. In his essays and novels, he wrote about the perils of modern civilisation. In Point Counter Point, excessive intellectualism, relying as it does on science and technology, leads to sterility. Can a pure art like music restore the wholeness of being? This is the dilemma raised by the last chapter of the novel. The issue is too complex to take a definite answer. Moreover, literature never gives answers. What it can give, instead, is a sense of restless questioning of the most troubling aspects of our existence. That is precisely what students have to be assisted to look for in novels like Point Counter Point through performance.

Performance puts the scene under their eyes and in their ears. While silent reading is by definition an experience that one has in some sort of "solitary confinement", performance ensures a communal, close to first-hand experience, in which not only the music as a referent participates, but also the characters' voices are actually heard and the drama of the scene is actually enacted. Thus, from the experience of the dramatic force of the scene, students can move on to further explorations of the text.

\section{References}

Baker, R. (1974). Spandrell's "Lydian Heaven”. Moral Masochism and the Centrality of Spandrell in Huxley's "Point Counter Point”. Criticism, 16(2), 120-135.

Birnbaum, M. (2009). Aldous Huxley: A Quest for Values. Rutgers, NY: Transaction Publishers. Calingacion, B. D. (2002). Literature Alive. A Performative Approach in Teaching Literature. Retrieved from http://magyarszak.uni-miskolc.hu/kiadvanyok/drama20o2/ea/belen.htm Hogarth, B. (1935). Aldous Huxley as Music Critic. The Musical Times, 76(1114), 1079-1082. Huxley, A. (1994) Point Counter Point. Los Angeles: Vintage.

Noica, C. (2002). Jurnal filosofic. București: Humanitas.

Schiller, F. [1909-14]. Letters upon the Aesthetic Education of Man. Retrieved from http://www. bartleby.com/32/502.html Wolf, W. (1999) The Musicalization of Fiction. A Study in the Theory and History of Intermediality. 


\section{Biographical note}

DANA BĂDULESCU holds a PhD in Philology following the defense of the thesis "Impressionistic Modes and Metaphoric Structures in E. M. Forster's Fiction and Criticism". She teaches modernist and postmodernist British and American literature, basic elements of literary theory and critical thinking, transculturalism, poetics and translations. She has translated books of history, philosophy, poetry, literary theory, international relations, and, most recently, Bill Bryson's book Down Under published in 2014. She has published a series of articles on modernism and postmodernism, key modernist and postmodernist writers and texts. She authored a textbook on modernism, a textbook on the nineteenth and twentieth century British novel and a book on postmodernism. Between October 2010 and March 2013 she was the receiver of a POSDRU postdoctoral grant for a project on Salman Rushdie and democracy. Since 2010 her research has been focusing on today's migrancy, hybridity, transnationalism and transculturalism. In December 2014, she formed a national research network which joined ISCH COST Action IS 1404 "Evolution of reading in the age of digitisation (E-READ).” Her most recent book Rushdie's Cross-pollinations was published in 2013 . 